\title{
Study on the Plugging System of the Lower Ancient High Loss Zone in Changqing Gas Field
}

\author{
Yan Gao', Zuwen Wang1, Xiuli Shao1*, Dichen Tan², Erping Liu ${ }^{3}$ \\ ${ }^{1}$ Chuanqing Drilling Engineering Company Underground Operation Company, Xi'an, China \\ ${ }^{2}$ Yangtze University, Jingzhou, China \\ ${ }^{3}$ Liaohe Oil Safety and Environment Protection Technical Supervision Center, Panjin, China \\ Email: gaoyan_2@163.com, ${ }^{\star}$ cj_shaoxl@cnpc.com.cn
}

How to cite this paper: Gao, Y., Wang, Z.W., Shao, X.L., Tan, D.C. and Liu, E.P. (2021) Study on the Plugging System of the Lower Ancient High Loss Zone in Changqing Gas Field. Open Journal of Yangtze Gas and Oil, 6, 1-12.

https://doi.org/10.4236/ojogas.2021.61001

Received: October 19, 2020

Accepted: December 20, 2020

Published: December 23, 2020

Copyright () 2021 by author(s) and Scientific Research Publishing Inc. This work is licensed under the Creative Commons Attribution International License (CC BY 4.0).

http://creativecommons.org/licenses/by/4.0/

\section{Abstract}

At present, in the workover operations of old gas wells in the Changqing Gas Field, due to years of exploitation in the production layer, pressure deficits, and general leakage during the well killing, the well must be plugged before the well can be killed. In particular, the fracture-cavity type fractures of the lower paleocarbonate reservoirs have serious leakage. Traditional plugging materials and traditional plugging materials and methods have some limitations in dealing with leakage problems. Therefore, a composite plugging system using polymer solution as the base carrier fluid, multi-particle size rigid particles, expandable particles and modified fibers is developed. Its formula is: water $+2 \%$ polyacrylamide $+0.1 \% \mathrm{~N}, \mathrm{~N}$-methylene bisacrylamide polymer gel is the base carrier fluid; the formulation of the particle plugging agent was continuously optimized through the CDL-II high temperature and high pressure dynamic and static plugging ability to plug the core. The final formulation of the plugging agent is: 1) $20 \%$ rigid particles $(5 \mathrm{~mm}, 1 \mathrm{~mm}, 0.5$ mm CCP-3 ratio 4:2:1) + 1\% 3 mm expanded particles SMK-1 + 1\% $1-2 \mathrm{~mm}$ fiber SRXW-10; 2) $20 \%$ rigid particles ( $3 \mathrm{~mm}, 0.1 \mathrm{~mm}, 0.05 \mathrm{~mm}$ CCP-3 ratio 3:2:1) + 1\% 3 mm expanded particles SMK-1 + 1\% $1-2$ mm fiber SRXW-10. The water swelling multiples of the granular plugging agent in salt water are all above 7 times, which meets the requirements of leak-proof plugging operations under high salinity; $3 \% \mathrm{HCl}$ is selected as the gel breaker, and the plugging system has a gel breaking rate of $95 \%$; through the water plugging and profile control experimental system, the sand-filled pipe is used to simulate the plugging effect under high temperature and high pressure, and the plugging system can be sealed for 5 days at a high temperature of $110^{\circ} \mathrm{C}$ and a high pressure of $20 \mathrm{MPa}$ to achieve a good plugging of the formation. It is expected that the developed plugging system has a good application prospect 
in future workover operations.

\section{Keywords}

Lower Ancient High Loss Layer, Plugging Gel, Particle Plugging Agent, Gel Breaking Performance, Plugging Performance

\section{Introduction}

The Changqing Gas Field is a typical gas field with "low permeability, low pressure and low abundance". After long-term mining, the formation pressure coefficient dropped to about 0.5 [1] [2] [3]. In order for the oil and gas wells in the Changqing block to resume normal production, it is necessary to restore the formation force coefficient through workover operations. At present, in workover operations, due to years of mining, pressure deficits, and common losses during well killing, the well must be plugged before killing, especially the fractures of the lower paleocarbonate reservoir, where the leakage is more serious [4] [5] [6]. In the process of workover operations, traditional plugging materials and methods are prone to poor plugging effect, repeated leakage or flowback difficulties when dealing with leakage problems, and plugging the pay zone, affecting productivity after workover, etc. [7]. This research relies on the Yangtze University Oilfield Chemistry Laboratory and project team members to develop a composite plugging system that uses polymer solutions, multi-particle size temporary plugging particles, and modified fibers to realize the effective plugging of perforation holes.

\section{Development of Plugging Gel}

The polymer commonly used in oil fields is polyacrylamide, which can be cross-linked with inorganic or organic cross-linking agents [8]. Common inorganic crosslinking agents have poor temperature resistance and cannot withstand the high temperature and high pressure environment of the formation, so organic crosslinking agents are selected for crosslinking. This article selects polyacrylamide (concentration of $2 \%$ ); cross-linking agents are polyamine organics (called MTA), N,N-methylenebisacrylamide (BIS) and phenol, all at a concentration of $0.1 \%$. To evaluate the gelation of the crosslinking agent at $120^{\circ} \mathrm{C}$, a high-temperature roller heating furnace is used, which only heats and does not roll, which can better simulate the underground plugging process [9]. The gelation status of the crosslinking agent at $120^{\circ} \mathrm{C}$ is evaluated, as shown in Table 1.

It can be seen from Table 1 that polyacrylamide can be gelled in the case of three crosslinking agents. Because phenol pollutes the environment, and the pumpability of MTA is a bit worse than that of BIS as a crosslinking agent, it is finally determined that water + polyacrylamide HPAM + BIS (N, N-methylene) Bisacrylamide) system. 
Table 1. Gelation status of polyacrylamide and crosslinking agent.

\begin{tabular}{ccc}
\hline Crosslinking agent & Gel forming & Pumpable \\
\hline Phenol & Gelled & Easy \\
Phenol & Gelled & Easy \\
MTA & Gelled & Harder \\
MTA & Gelled & Harder \\
BIS & Gelled & Easy \\
BIS & Gelled & Easy \\
\hline
\end{tabular}

\section{Determination of Plugging Gel Formulation}

The system formula is initially set as $2 \%$ polyacrylamide $+0.1 \%$ BIS, and the experimental temperature was $100^{\circ} \mathrm{C}-120^{\circ} \mathrm{C}$. Use single factor analysis to determine the optimal increase.

1) Determination of polyacrylamide concentration

The concentration of polyacrylamide is $1.5 \%, 2 \%, 2.5 \%$, the concentration of BIS is $0.1 \%$, the experimental temperature is $100^{\circ} \mathrm{C}-120^{\circ} \mathrm{C}$, and the gel formation is shown in Table 2.

Table 2. The effect of different concentrations of polyacrylamide on gel formation.

\begin{tabular}{ccccc}
\hline Concentration & \multicolumn{3}{c}{ Gel time $(\mathrm{h})$} & $\begin{array}{c}\text { Initial viscosity } \\
\text { (mPa.s) }\end{array}$ \\
\cline { 2 - 4 } & $100^{\circ} \mathrm{C}$ & $110^{\circ} \mathrm{C}$ & $120^{\circ} \mathrm{C}$ & 3000 \\
$2.0 \%$ & 6 & 4 & 3 & 5500 \\
$2.5 \%$ & 4 & 3 & 2 & 8850 \\
\hline
\end{tabular}

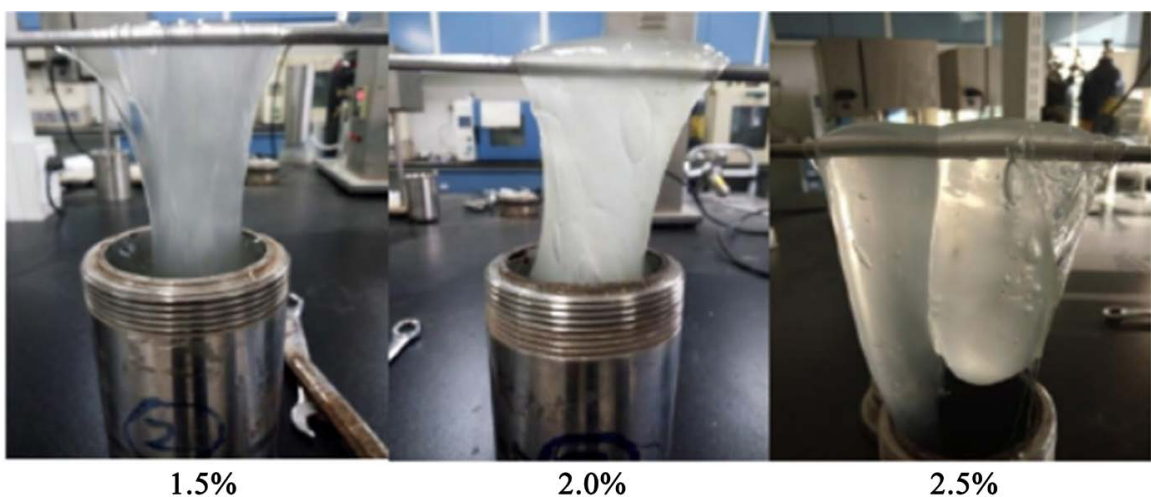

Figure 1. Gelation pictures of polyacrylamide at different concentrations at $100^{\circ} \mathrm{C}$.

Figure 1 shows the gelation of different concentrations of polyacrylamide at $100^{\circ} \mathrm{C}$. Comprehensive Table 2 and Figure 1 show that the viscosity and elasticity of $1.5 \%$ are much worse than that of $2 \%$ and $2.5 \%$, and the gel time is longer., The blocking ability is poor; the performance difference between $2 \%$ and $2.5 \%$ is not much, but the initial viscosity when the concentration reaches $2.5 \%$ is 8550 $\mathrm{mPa} \cdot \mathrm{s}$, and the initial pumpability is too poor, so the initial pumpability and gel 
time are integrated And the elasticity after gelation, confirm that the polyacrylamide concentration is $2 \%$.

2) Determination of BIS concentration

The concentration of BIS is $0.05 \%, 0.1 \%, 0.15 \%$, the concentration of polyacrylamide is $2 \%$, the experiment temperature is $100^{\circ} \mathrm{C}-120^{\circ} \mathrm{C}$, and the gel formation is shown in Table 3.

Table 3. Gelation data of different concentrations of BIS.

\begin{tabular}{ccccc}
\hline Concentration & \multicolumn{3}{c}{ Gel time $(\mathrm{h})$} & $\begin{array}{c}\text { Initial viscosity } \\
(\mathrm{mPa} \cdot \mathrm{s})\end{array}$ \\
\cline { 2 - 5 } & $100^{\circ} \mathrm{C}$ & $110^{\circ} \mathrm{C}$ & $120^{\circ} \mathrm{C}$ & 5780 \\
$0.05 \%$ & 5 & 4 & 3 & 5500 \\
$0.10 \%$ & 4 & 3 & 2 & 5650 \\
$0.15 \%$ & 3 & 2 & 1 & \\
\hline
\end{tabular}

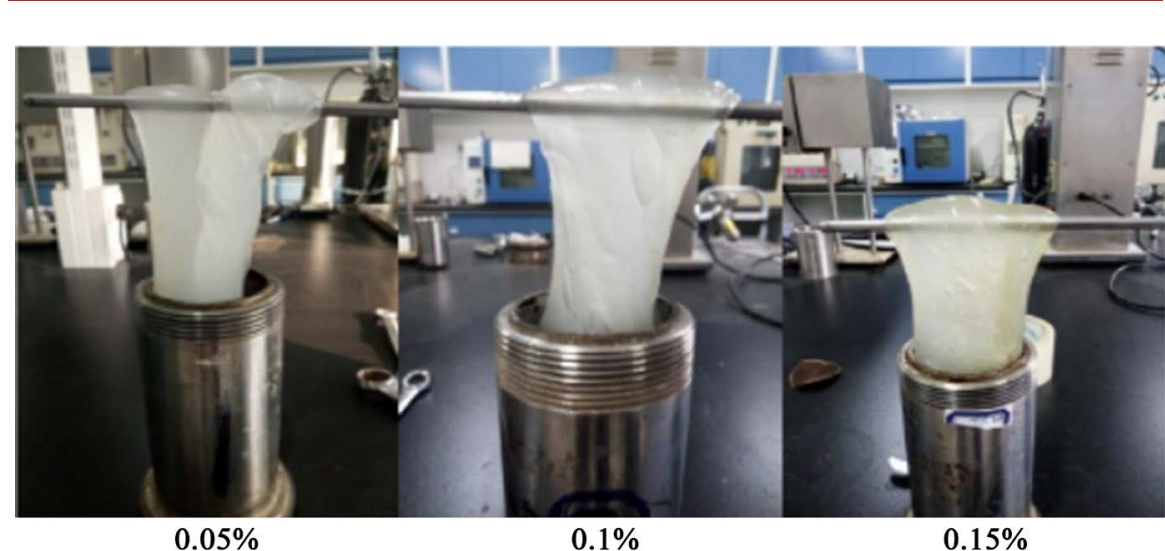

Figure 2. Gelation pictures of different concentrations of BIS at $100^{\circ} \mathrm{C}$.

From Table 3 data and observation of Figure 2 it can be seen that the $0.05 \%$ concentration of BIS has a long time to gel, and the strength after gelation is low, and the blocking ability is poor; although the $0.15 \%$ concentration of BIS has less gel time, but due to excessive Cross-linking has poor stability. Therefore, combining the stability of gel formation, gel time and strength after gel formation, the concentration of BIS is determined to be $0.1 \%$.

Through the above experimental research, it is finally determined that the final formulation of the plugging gel is water $+2 \%$ polyacrylamide $+0.1 \%$ BIS. The test temperature range of the plugging gel is $100^{\circ} \mathrm{C} \sim 120^{\circ} \mathrm{C}$ and the stability of the gel can still be maintained, so the temperature resistance of the system is $\geq 100^{\circ} \mathrm{C}$.

\section{Determination of Particle Plugging Agent}

The experimental instrument is a CDL-II high temperature and high pressure dynamic and static plugging experimental device. Through the indoor artificial core (12 $\mathrm{mm}$ aperture), the advection pump uses a flow rate of $5-10 \mathrm{~mL} / \mathrm{min}$ to displace the plugging system with plugging agent to make it pass For man-made fractured cores, the pressure is maintained for 10 minutes, the filter loss is less 
than $20 \mathrm{ml}$ as the standard, and the experimental temperature is $110^{\circ} \mathrm{C}$. The formulation of the granular plugging agent is continuously optimized through the plugging ability of the core [10].

\subsection{Determination of Rigid Particle Plugging Agent}

\subsubsection{Determination of Particle Size Gradation}

CCP-3 is a rigid particle plugging agent, using 3 kinds of particle combinations, with $5 \mathrm{~mm}$ particles as the main body and $3 \mathrm{~mm}$ particles as the main body respectively, and the other two suitable particle size gradations are preferred. After investigation, the following combinations of particles were made.

1) Take $5 \mathrm{~mm}$ particles as the main body:

a) $5 \mathrm{~mm}+2 \mathrm{~mm}+1 \mathrm{~mm}$; b) $5 \mathrm{~mm}+2 \mathrm{~mm}+0.5 \mathrm{~mm}$; ) $5 \mathrm{~mm}+1 \mathrm{~mm}+0.5$ $\mathrm{mm}$;

2) With $3 \mathrm{~mm}$ particles as the main body:

a) $3 \mathrm{~mm}+0.5 \mathrm{~mm}+0.1 \mathrm{~mm}$; b) $3 \mathrm{~mm}+0.5 \mathrm{~mm}+0.05 \mathrm{~mm}$; ) $3 \mathrm{~mm}+0.1$ $\mathrm{mm}+0.05 \mathrm{~mm}$

The ratio of the three particles in the two formulations is $2: 1: 1$, the particle concentration is $10 \%$, and the plugging gel is used as the base carrier liquid to investigate the pressure resistance and plugging performance of the plugging agent with different particle size gradations. In order to determine the optimal particle size gradation, the experimental results are shown in Table 4 and Table 5.

Table 4. Evaluation of the plugging performance of CCP-3 with $5 \mathrm{~mm}$ particles as the main body in different particle size gradations.

\begin{tabular}{cccc}
\hline $\begin{array}{c}\text { Displacement pressure } \\
(\mathrm{MPa})\end{array}$ & \multicolumn{3}{c}{ Different particle size gradation } \\
\cline { 2 - 4 } & $(1)$ & $(2)$ & $(3)$ \\
\hline 1.5 & $11 \mathrm{~mL}$ & $10 \mathrm{~mL}$ & $8 \mathrm{~mL}$ \\
3.0 & $12 \mathrm{~mL}$ & $11 \mathrm{~mL}$ & $9 \mathrm{~mL}$ \\
5.0 & $14 \mathrm{~mL}$ & $13 \mathrm{~mL}$ & $10 \mathrm{~mL}$ \\
7.5 & $16 \mathrm{~mL}$ & $15 \mathrm{~mL}$ & $12 \mathrm{~mL}$ \\
10.0 & $18 \mathrm{~mL}$ & $16 \mathrm{~mL}$ & $13 \mathrm{~mL}$ \\
12.0 & $27 \mathrm{~mL}$ & $25 \mathrm{~mL}$ & $20 \mathrm{~mL}$ \\
\hline
\end{tabular}

Table 5. Evaluation of the plugging performance of CCP-3 with $3 \mathrm{~mm}$ particles as the main body in different particle size gradations.

\begin{tabular}{cccc}
\hline $\begin{array}{c}\text { Displacement pressure } \\
(\mathrm{MPa})\end{array}$ & \multicolumn{3}{c}{ Different particle size gradation } \\
\cline { 2 - 4 } 1.5 & $12 \mathrm{~mL}$ & $(2)$ & $(3)$ \\
3.0 & $13 \mathrm{~mL}$ & $11 \mathrm{~mL}$ & $9 \mathrm{~mL}$ \\
5.0 & $14 \mathrm{~mL}$ & $12 \mathrm{~mL}$ & $10 \mathrm{~mL}$ \\
7.5 & $17 \mathrm{~mL}$ & $13 \mathrm{~mL}$ & $11 \mathrm{~mL}$ \\
10.0 & $18 \mathrm{~mL}$ & $15 \mathrm{~mL}$ & $13 \mathrm{~mL}$ \\
12.0 & $26 \mathrm{~mL}$ & $17 \mathrm{~mL}$ & $15 \mathrm{~mL}$ \\
\hline
\end{tabular}


According to Table 4 and Table 5, the optimal particle size combination with $5 \mathrm{~mm}$ particles as the main body is determined, which is $5 \mathrm{~mm}+1 \mathrm{~mm}+0.5$ $\mathrm{mm}$; the optimal particle size combination with $3 \mathrm{~mm}$ particles as the main body, is $3 \mathrm{~mm}+0.1 \mathrm{~mm}+0.05 \mathrm{~mm}$, which can withstand a pressure of $10 \mathrm{MPa}$.

\subsubsection{Determination of the Ratio of Large and Small Particles}

Add $10 \%$ of the particle plugging agent to the plugging gel to investigate the compression resistance and plugging performance of the particles in different proportions. The experimental results are shown in Table 6 and Table 7.

Table 6. Evaluation of the plugging performance of CCP-3 with $5 \mathrm{~mm}$ particles as the main body under different proportions.

\begin{tabular}{|c|c|c|c|c|}
\hline \multirow{2}{*}{$\begin{array}{c}\text { Displacement } \\
\text { pressure }(\mathrm{MPa})\end{array}$} & \multicolumn{4}{|c|}{ The ratio of three kinds of particles } \\
\hline & $4: 1: 1$ & $4: 1: 2$ & $4: 2: 1$ & $2: 1: 1$ \\
\hline 1.5 & $10 \mathrm{~mL}$ & $9 \mathrm{~mL}$ & $8 \mathrm{~mL}$ & $9 \mathrm{~mL}$ \\
\hline 3.0 & $11 \mathrm{~mL}$ & $10 \mathrm{~mL}$ & $8 \mathrm{~mL}$ & $9 \mathrm{~mL}$ \\
\hline 5.0 & $13 \mathrm{~mL}$ & $12 \mathrm{~mL}$ & $9 \mathrm{~mL}$ & $10 \mathrm{~mL}$ \\
\hline 7.5 & $15 \mathrm{~mL}$ & $14 \mathrm{~mL}$ & $9 \mathrm{~mL}$ & $11 \mathrm{~mL}$ \\
\hline 10.0 & $16 \mathrm{~mL}$ & $17 \mathrm{~mL}$ & $12 \mathrm{~mL}$ & $13.5 \mathrm{~mL}$ \\
\hline 12.5 & $25 \mathrm{~mL}$ & $23 \mathrm{~mL}$ & $21 \mathrm{~mL}$ & $22 \mathrm{~mL}$ \\
\hline
\end{tabular}

Table 7. Plugging performance evaluation of CCP-3 with $3 \mathrm{~mm}$ particles as the main body under different ratios.

\begin{tabular}{|c|c|c|c|c|}
\hline \multirow{2}{*}{$\begin{array}{c}\text { Displacement } \\
\text { pressure }(\mathrm{MPa})\end{array}$} & \multicolumn{4}{|c|}{ The ratio of three kinds of particles } \\
\hline & $3: 1: 1$ & $3: 1: 2$ & $3: 2: 1$ & $3: 2: 2$ \\
\hline 1.5 & $10 \mathrm{~mL}$ & $8 \mathrm{~mL}$ & $7 \mathrm{~mL}$ & $9.5 \mathrm{~mL}$ \\
\hline 3.0 & $12 \mathrm{~mL}$ & $11 \mathrm{~mL}$ & $9 \mathrm{~mL}$ & $12 \mathrm{~mL}$ \\
\hline 5.0 & $13 \mathrm{~mL}$ & $12 \mathrm{~mL}$ & $11 \mathrm{~mL}$ & $12.5 \mathrm{~mL}$ \\
\hline 7.5 & $15 \mathrm{~mL}$ & $14 \mathrm{~mL}$ & $12 \mathrm{~mL}$ & $14 \mathrm{~mL}$ \\
\hline 10.0 & $17 \mathrm{~mL}$ & $15 \mathrm{~mL}$ & $14 \mathrm{~mL}$ & $16 \mathrm{~mL}$ \\
\hline 12.5 & $24 \mathrm{~mL}$ & $21 \mathrm{~mL}$ & $20 \mathrm{~mL}$ & $22 \mathrm{~mL}$ \\
\hline
\end{tabular}

According to Table 6 and Table 7, the optimal particle size ratio with $5 \mathrm{~mm}$ particles as the main body is determined, which is $4: 2: 1$; the optimal particle size ratio with $3 \mathrm{~mm}$ particles as the main body, is $3: 2: 1$, which can bear Pressure of $10 \mathrm{MPa}$.

\subsubsection{Determination of the Concentration of Rigid Particles}

According to the above ratio, the plugging performance of different dosages under the two formulas was evaluated. The plugging experiment data are as follows:

According to Table 8 and Table 9, the optimal dosage of the two formulations is $20 \%$, and the pressure can reach $10.0 \mathrm{MPa}$, and there is no obvious leakage. 
Table 8. The plugging effect of CCP-3 with $5 \mathrm{~mm}$ particles as the main body under different dosages.

\begin{tabular}{cccc}
\hline \multirow{2}{*}{$\begin{array}{c}\text { Displacement pressure } \\
(\mathrm{MPa})\end{array}$} & \multicolumn{3}{c}{ CCP-3 for large and small particles } \\
\cline { 2 - 4 } & $10 \%$ & $20 \%$ & $30 \%$ \\
\hline 1.5 & $8 \mathrm{~mL}$ & $7 \mathrm{~mL}$ & $8 \mathrm{~mL}$ \\
3.0 & $9 \mathrm{~mL}$ & $7 \mathrm{~mL}$ & $9 \mathrm{~mL}$ \\
5.0 & $11 \mathrm{~mL}$ & $7.5 \mathrm{~mL}$ & $10 \mathrm{~mL}$ \\
7.5 & $14 \mathrm{~mL}$ & $9 \mathrm{~mL}$ & $13 \mathrm{~mL}$ \\
10.0 & $15.5 \mathrm{~mL}$ & $10 \mathrm{~mL}$ & $15 \mathrm{~mL}$ \\
12.0 & $28 \mathrm{~mL}$ & $24 \mathrm{~mL}$ & $30 \mathrm{~mL}$ \\
\hline
\end{tabular}

Table 9. The plugging effect of CCP-3 with $3 \mathrm{~mm}$ particles as the main body under different dosages.

\begin{tabular}{cccc}
\hline $\begin{array}{c}\text { Displacement pressure } \\
(\mathrm{MPa})\end{array}$ & \multicolumn{3}{c}{ CCP-3 for large and small particles } \\
\cline { 2 - 4 } 1.5 & $10 \%$ & $20 \%$ & $30 \%$ \\
3.0 & $8.5 \mathrm{~mL}$ & $7 \mathrm{~mL}$ & $8 \mathrm{~mL}$ \\
5.0 & $9 \mathrm{~mL}$ & $8 \mathrm{~mL}$ & $9 \mathrm{~mL}$ \\
7.5 & $10 \mathrm{~mL}$ & $9 \mathrm{~mL}$ & $10 \mathrm{~mL}$ \\
10.0 & $11.5 \mathrm{~mL}$ & $11 \mathrm{~mL}$ & $13 \mathrm{~mL}$ \\
12.0 & $13 \mathrm{~mL}$ & $12 \mathrm{~mL}$ & $17 \mathrm{~mL}$ \\
\hline
\end{tabular}

\subsection{Determination of Expandable Particles}

\section{Optimization of Expandable Particles}

Adopt BGRL-2 roller heating furnace, the base slurry is plugging gel, add 3\% expandable particles, heat roll at $110^{\circ} \mathrm{C}$ for 16 hours, observe the change of expandable particles at $110^{\circ} \mathrm{C}$ [11]. The evaluation results are shown in Table 10:

Table 10. Evaluation of temperature resistance of different expansive particles.

\begin{tabular}{cc}
\hline Material name & $110^{\circ} \mathrm{C}$ \\
\hline SJ-6 & Discoloration in appearance \\
GLP-1 & The appearance is slightly discolored \\
LPC-4 & Discoloration in appearance \\
SMK-1 & No obvious change in appearance \\
\hline
\end{tabular}

According to Table 10, except for SMK-1, the appearance of other materials has changed more or less. Therefore, $3 \mathrm{~mm} \mathrm{SMK-1}$ is selected as the swelling particles to play a plugging role in the plugging process.

The $3 \mathrm{~mm}$ SMK-1 was selected, combined with the above-mentioned ratio and concentration of the granular plugging agent, and the plugging experimental data for investigating the plugging and compressive performance are as follows: 
Table 11. The blocking effect of CCP-3 with $5 \mathrm{~mm}$ particles as the main body at different SMK-1 concentrations.

\begin{tabular}{cccc}
\hline \multirow{2}{*}{$\begin{array}{c}\text { Displacement pressure } \\
(\text { MPa })\end{array}$} & \multicolumn{3}{c}{ SMK-1 dosage } \\
\cline { 2 - 4 } & $0.5 \%$ & $1 \%$ & $1.5 \%$ \\
\hline 1.5 & $7 \mathrm{~mL}$ & $6 \mathrm{~mL}$ & $8 \mathrm{~mL}$ \\
3.0 & $8 \mathrm{~mL}$ & $6 \mathrm{~mL}$ & $9 \mathrm{~mL}$ \\
5.0 & $9 \mathrm{~mL}$ & $7 \mathrm{~mL}$ & $10 \mathrm{~mL}$ \\
7.5 & $11 \mathrm{~mL}$ & $8 \mathrm{~mL}$ & $12 \mathrm{~mL}$ \\
10 & $12 \mathrm{~mL}$ & $9 \mathrm{~mL}$ & $14 \mathrm{~mL}$ \\
12.5 & $14 \mathrm{~mL}$ & $11 \mathrm{~mL}$ & $15 \mathrm{~mL}$ \\
15 & $27 \mathrm{~mL}$ & $25 \mathrm{~mL}$ & $29 \mathrm{~mL}$ \\
\hline
\end{tabular}

Table 12. The blocking effect of CCP-3 with $3 \mathrm{~mm}$ particles as the main body under different SMK-1 concentrations.

\begin{tabular}{crcc}
\hline \multirow{2}{*}{$\begin{array}{c}\text { Displacement pressure } \\
(\mathrm{MPa})\end{array}$} & \multicolumn{3}{c}{ SMK-1 dosage } \\
\cline { 2 - 4 } 1.5 & $7.5 \mathrm{~mL}$ & $1 \%$ & $1.5 \%$ \\
\hline 3.0 & $9 \mathrm{~mL}$ & $6 \mathrm{~mL}$ & $8.5 \mathrm{~mL}$ \\
5.0 & $10 \mathrm{~mL}$ & $7 \mathrm{~mL}$ & $10 \mathrm{~mL}$ \\
7.5 & $11.5 \mathrm{~mL}$ & $7 \mathrm{~mL}$ & $11.5 \mathrm{~mL}$ \\
10 & $13 \mathrm{~mL}$ & $8 \mathrm{~mL}$ & $13 \mathrm{~mL}$ \\
12.5 & $16 \mathrm{~mL}$ & $9 \mathrm{~mL}$ & $14 \mathrm{~mL}$ \\
15 & $30 \mathrm{~mL}$ & $11 \mathrm{~mL}$ & $17 \mathrm{~mL}$ \\
\hline
\end{tabular}

According to the Table 11 and Table 12, the pressure under the three concentrations can reach $12.5 \mathrm{MPa}$, and there is no obvious leakage. In summary, adding $1 \%$ of brucite has the smallest filtration loss, so the optimal addition of brucite is $1 \%$.

\subsection{Optimum Fiber}

Select a $1 \sim 2 \mathrm{~mm}$ SRXW-10 fiber, combined with the above-mentioned granular plugging agent, and investigate the plugging and compressive performance. The plugging experimental data are shown in Table 13 and Table 14.

Table 13. The plugging effect of CCP-3 with $5 \mathrm{~mm}$ particles as the main body under different fiber concentrations.

\begin{tabular}{cccc}
\hline $\begin{array}{c}\text { Displacement pressure } \\
(\mathrm{MPa})\end{array}$ & $0.5 \%$ & Fiber addition & \\
\cline { 2 - 4 } & $6 \mathrm{~mL}$ & $5 \mathrm{~mL}$ & $1.5 \%$ \\
\hline 1.5 & $7 \mathrm{~mL}$ & $5 \mathrm{~mL}$ & $7 \mathrm{~mL}$ \\
3.0 & $7 \mathrm{~mL}$ & $6 \mathrm{~mL}$ & $10 \mathrm{~mL}$ \\
\hline 5.0 & & & \\
\hline
\end{tabular}




\begin{tabular}{rrrr}
\hline 7.5 & $8 \mathrm{~mL}$ & $7 \mathrm{~mL}$ & $11 \mathrm{~mL}$ \\
10 & $10 \mathrm{~mL}$ & $9 \mathrm{~mL}$ & $12 \mathrm{~mL}$ \\
12.5 & $12 \mathrm{~mL}$ & $10 \mathrm{~mL}$ & $14 \mathrm{~mL}$ \\
15 & $14 \mathrm{~mL}$ & $11 \mathrm{~mL}$ & $16 \mathrm{~mL}$ \\
17.5 & $30 \mathrm{~mL}$ & $28 \mathrm{~mL}$ & $35 \mathrm{~mL}$ \\
\hline
\end{tabular}

Table 14. The plugging effect of CCP-3 with $3 \mathrm{~mm}$ particles as the main body under different fiber concentrations.

\begin{tabular}{crcc}
\hline \multirow{2}{*}{$\begin{array}{c}\text { Displacement pressure } \\
(\mathrm{MPa})\end{array}$} & \multicolumn{3}{c}{ Fiber addition } \\
\cline { 2 - 4 } & $0.5 \%$ & $1 \%$ & $1.5 \%$ \\
\hline 1.5 & $6.5 \mathrm{~mL}$ & $5 \mathrm{~mL}$ & $7 \mathrm{~mL}$ \\
3.0 & $8 \mathrm{~mL}$ & $6 \mathrm{~mL}$ & $8 \mathrm{~mL}$ \\
5.0 & $9 \mathrm{~mL}$ & $6 \mathrm{~mL}$ & $8 \mathrm{~mL}$ \\
7.5 & $10.5 \mathrm{~mL}$ & $7 \mathrm{~mL}$ & $9 \mathrm{~mL}$ \\
10 & $11.5 \mathrm{~mL}$ & $8 \mathrm{~mL}$ & $11 \mathrm{~mL}$ \\
12.5 & $14 \mathrm{~mL}$ & $10 \mathrm{~mL}$ & $14 \mathrm{~mL}$ \\
15 & $16 \mathrm{~mL}$ & $12 \mathrm{~mL}$ & $16 \mathrm{~mL}$ \\
17.5 & $36 \mathrm{~mL}$ & $30 \mathrm{~mL}$ & $34 \mathrm{~mL}$ \\
\hline
\end{tabular}

According to the above table, the pressure under the three concentrations can reach $15 \mathrm{MPa}$, and there is no obvious leakage. In summary, adding $1 \%$ of acid-soluble fiber has the smallest total fluid loss, so the optimal addition of SRXW-10 is $1 \%$.

\section{Research on the Performance of the Plugging System}

\subsection{Research on the Gel Breaking Performance of the Plugging System}

As a gel breaker, $\mathrm{HCl}$ can not only break gel but also acid-soluble particle plugging agent [12]. The plugging gel is used as the base carrier fluid, and the above-developed particle plugging agent is added separately. The experimental temperature is $110^{\circ} \mathrm{C}$. The gel breaking conditions are shown in Table 15 and Table 16:

Table 15. CCP-3 glue breaking situation with $5 \mathrm{~mm}$ particles as the main body.

\begin{tabular}{cccc}
\hline \multirow{2}{*}{ Time } & \multicolumn{3}{c}{ HCl concentration } \\
\cline { 2 - 4 } & $1 \%$ & $3 \%$ & $5 \%$ \\
\hline $12 \mathrm{~h}$ & $366 \mathrm{~g}$ & $377 \mathrm{~g}$ & $370 \mathrm{~g}$ \\
$24 \mathrm{~h}$ & $256 \mathrm{~g}$ & $63 \mathrm{~g}$ & $219 \mathrm{~g}$ \\
$36 \mathrm{~h}$ & $201 \mathrm{~g}$ & $19 \mathrm{~g}$ & $20 \mathrm{~g}$ \\
\hline
\end{tabular}


Continued

\begin{tabular}{crcc}
\hline $48 \mathrm{~h}$ & $115 \mathrm{~g}$ & $19 \mathrm{~g}$ & $20 \mathrm{~g}$ \\
$60 \mathrm{~h}$ & $105 \mathrm{~g}$ & $19 \mathrm{~g}$ & $20 \mathrm{~g}$ \\
$72 \mathrm{~h}$ & $96 \mathrm{~g}$ & $19 \mathrm{~g}$ & $20 \mathrm{~g}$ \\
Glue breaking rate & $73.8 \%$ & $95 \%$ & $94.6 \%$ \\
\hline
\end{tabular}

Table 16. CCP-3 gel breaking situation with $3 \mathrm{~mm}$ particles as the main body.

\begin{tabular}{cccc}
\hline \multirow{2}{*}{ Time } & \multicolumn{3}{c}{$\mathrm{HCl}$ concentration } \\
\cline { 2 - 4 } & $1 \%$ & $3 \%$ & $5 \%$ \\
\hline $0 \mathrm{~h}$ & $365 \mathrm{~g}$ & $365 \mathrm{~g}$ & $372 \mathrm{~g}$ \\
$12 \mathrm{~h}$ & $306 \mathrm{~g}$ & $223 \mathrm{~g}$ & $205 \mathrm{~g}$ \\
$24 \mathrm{~h}$ & $292 \mathrm{~g}$ & $18 \mathrm{~g}$ & $19 \mathrm{~g}$ \\
$36 \mathrm{~h}$ & $281 \mathrm{~g}$ & $18 \mathrm{~g}$ & $19 \mathrm{~g}$ \\
$48 \mathrm{~h}$ & $265 \mathrm{~g}$ & $18 \mathrm{~g}$ & $19 \mathrm{~g}$ \\
$60 \mathrm{~h}$ & $218 \mathrm{~g}$ & $18 \mathrm{~g}$ & $19 \mathrm{~g}$ \\
$72 \mathrm{~h}$ & $133 \mathrm{~g}$ & $18 \mathrm{~g}$ & $19 \mathrm{~g}$ \\
Glue breaking rate & $60.7 \%$ & $95.1 \%$ & $94.9 \%$ \\
\hline
\end{tabular}

When the two particle plugging agents are used as the base carrier fluid for the plugging gel, the $3 \%$ and $5 \%$ concentration of $\mathrm{HCl}$ have the highest gel breaking rate at the same time, reaching $95 \%$, and the residual is the least. Considering the cost and gel breaking rate, plugging, the best concentration of the system for gel breaking is $3 \%$; both of them can complete the gel breaking within $24 \mathrm{~h}$.

\subsection{Evaluation of Swelling Performance of Granular Plugging Agent under Different Water Quality}

Under normal temperature conditions, take the dried granular plugging agent of the same quality and put them into three identical beakers at the same time. The three beakers are added with different salinity salt solutions to measure different absorption media [13]. Water swellability under water absorption, the experimental results are shown in Figure 3.

It can be seen from Figure 3 that as the salt concentration increases, the water swelling rate of the particulate plugging agent increases. Since the swelling multiples of granular plugging agents in salt water are all over 7 times [14], they meet the requirements of leak-proof plugging operations under high salinity.

\subsection{Evaluation of the Plugging Performance of the Plugging System}

Through the water plugging and profile control experimental system, the sand-filled pipe is used to simulate the plugging effect under high temperature and high pressure, and three sets of parallel experiments are carried out [15]. The experiment uses artificial core (12 $\mathrm{mm}$ aperture), the experiment temperature is $110^{\circ} \mathrm{C}$, and the experimental data are shown in Table 17 : 


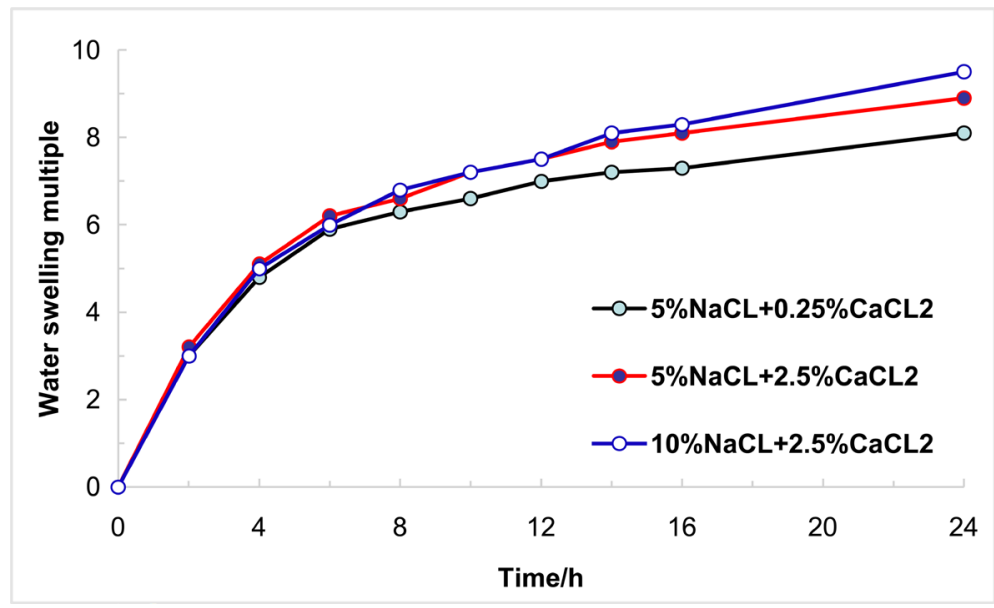

Figure 3. The influence of different salinity on the water swellability of the plugging agent.

Table 17. Pressure resistance and plugging situation of the plugging system.

\begin{tabular}{cccccc}
\hline Plugging system & $\begin{array}{c}\text { Experiment } \\
\text { number }\end{array}$ & $\begin{array}{c}\text { temperature/ }{ }^{\circ} \mathrm{C} \\
\text { Pressure } \\
\text { time }\end{array}$ & $\begin{array}{c}\text { Maximum } \\
\text { compression/MPa }\end{array}$ & Gelling effect \\
\hline $\begin{array}{c}\text { Plugging system with 5 } \\
\text { mm particles as the main } \\
\text { body }\end{array}$ & 1 & 110 & 5 days & 20 & Successfully blocked \\
$\begin{array}{c}\text { Plugging system with 3 } \\
\text { mm particles as the main } \\
\text { body }\end{array}$ & 1 & 110 & 5 days & 20 & Successfully blocked \\
& 2 & 110 & 5 days & 20 & Successfully blocked \\
& 3 & 110 & 5 days & 20 & Successfully blocked \\
& 110 & 5 days & 20 & Successfully blocked \\
\hline
\end{tabular}

According to Table 17, at an experimental temperature of $110^{\circ} \mathrm{C}$, the sand-filled pipe plugging experiment was performed on the two particle plugging systems, and it was shown that both plugging systems can plug for 5 days under high temperature and high pressure conditions. Both plugging systems can achieve a good plugging effect on the formation.

\section{Conclusions}

1) A composite plugging system was developed using polymer solution, multi-diameter rigid particles, expandable particles and modified fibers. The formula is: a) water $+2 \%$ polyacrylamide $+0.1 \% \mathrm{~N}, \mathrm{~N}$-methylene bisacrylamide $+20 \%$ rigid particles $(5 \mathrm{~mm}, 1 \mathrm{~mm}, 0.5 \mathrm{~mm}$ CCP-3 ratio 4:2:1) + 1\% $3 \mathrm{~mm}$ expanded particles SMK-1 + 1\% $1-2 \mathrm{~mm}$ fiber SRXW -10 ; b) Water $+2 \%$ polyacrylamide $+0.1 \% \mathrm{~N}, \mathrm{~N}$-methylene bisacrylamide $+20 \%$ rigid particles $(3 \mathrm{~mm}, 0.1 \mathrm{~mm}, 0.05$ $\mathrm{mm}$ CCP-3 ratio is $3: 2: 1)+1 \%$ of $3 \mathrm{~mm}$ expanded particles SMK-1 $+1 \%$ of $1-2$ mm fiber SRXW-10.

2) The plugging system can plug for 5 days at a high temperature of $110^{\circ} \mathrm{C}$ and a high pressure of $20 \mathrm{MPa}$, and the plugging system can achieve a good plugging effect on the formation.

3) The water swelling multiples of the granular plugging agent in salt water 
are all above 7 times, which meets the requirements of leak-proof plugging operations under high salinity.

4) The plugging system uses $\mathrm{HCl}$ as the breaker, and the optimal concentration is $3 \%$.

\section{Conflicts of Interest}

The authors declare no conflicts of interest regarding the publication of this paper.

\section{References}

[1] Zhang, S.H., Luo, P.Y., et al. (1996) Reservoir Protection Technology. Petroleum Industry Press, Beijing.

[2] McGill, C.H., et al. (2016) Sealing Frequency of B104 Cells Declines Exponentially with Decreasing Transection Distance from the Axon Hillock. Experimental Neurology, 279, 149-158.

[3] Cai, L.S., Su, C.M. and Liu, J.H. (2010) Analysis of the Pressure-Bearing Capacity of the Leak-Prone Formation. Acta Petrolei Sinica, 31, 311-317.

[4] Lake, L.W., Johns, R., Rossen, W. and Pope, G. (2014) Fundamentals of Enhanced Oil Recovery. Society of Petroleum Engineers.

[5] Guo, H., Yang, C.H., Fan, J. and Yi, M.X. (2010) Research and Application of Temperature and Salt Resistance Profile Control and Flooding System for High Temperature and Low Permeability Reservoirs. Oilfield Chemistry, 27, 183-187.

[6] Qiu, Y., Wei, M., Bai, B. and Mao, C. (2017) Data Analysis and Application Guidelines for the Microgel Field Applications. Fuel, 210, 557-568. https://doi.org/10.1016/j.fuel.2017.08.094

[7] Meng, X.X. (2016) Study on the Synthesis of Water-Soluble Thermoplastic Phenolic Resin and the Characteristics of Deep Reservoir Control and Flooding. Doctoral Dissertation, China University of Petroleum, Beijing.

[8] Chen, Z.W. and Wang, Y.J. (2015) Application of High-Temperature Downhole Cross-Linking Consolidation Plugging Technology in Tahe Oilfield. Drilling Fluids and Completion Fluids, 32, 42-46.

[9] Li, J., Liu, W.T., et al. (2012) Performance Evaluation of High-Strength Salt-Resistant and Water-Absorbing Resin for Leak Plugging. Drilling and Completion Fluids, 29, 13-15.

[10] Wei, J.M., Ma, T. and Tang, D.Z. (2009) Research Status of Bulk Water Plugging and Profile Control Agents. Applied Chemical Industry, 38, 1517-1520.

[11] Jia, L.L., Tian, L.F., Liu, Z., et al. (2011) Progress in Research on Plugging Materials. Materials Research and Application, 5, 14-16.

[12] Yu, C. (2016) Research on Polymer Gel Plugging Technology. China University of Geosciences, Wuhan.

[13] Sun, J., Cui, M.R., Chen, H., et al. (2007) Development of a New Composite Plugging Material. Journal of Southwest Petroleum University, 29, 133-136.

[14] Xiao, B., Li, X.Y., Chen, Z.S., et al. (2008) Application of HHH Plugging Agent in Controlling Multi-Point Well Lost Circulation. Natural Gas Industry, 28, 55-57.

[15] Qin, Y., Liu, Y.L., Zhang, L.D., et al. (2016) Laboratory Study of Flexible Gel Particle Profile Control Agent. Fine Petrochemical Industry, 33, No. 4. 